Studia Judaica 19 (2016), nr 2 (38), s. 229-249

doi:10.4467/24500100STJ.16.011.6222

Maria Cieśla

\title{
Żydowscy celnicy w Wielkim Księstwie Litewskim w XVII-XVIII wieku
}

\author{
JEWISH TOLL COLLECTORS IN THE GRAND DUCHY OF LITHUANIA \\ IN THE SEVENTEENTH AND EIGHTEENTH CENTURIES
}

\begin{abstract}
The purpose of this article is to show the Jewish involvement in the toll collection in the Grand Duchy of Lithuania in the seventeenth and eighteenth centuries. The following aspects are explored: the legal position, the financial involvement and conditions of the everyday work of the Jewish toll collectors, as well as the conflicts connected with this profession. The author based her research upon mostly unknown primary sources, including Lithuanian treasury documents and different court acts. Upon examination of those sources it becomes clear that the Jews played a significant role in the tax collection in the Grand Duchy of Lithuania in that period. What is more, not only members of the economic elite were involved in the cooperation with the state treasury.
\end{abstract}

Keywords: Jewish toll collectors, Jewish economic elites.

Słowa kluczowe: żydowscy celnicy, żydowskie elity finansowe.

„Jedź do Litwy albo Rusi - Żydzi na cłach, Żydzi arendarzami, Żydzi mytnikami" utworów antyżydowskich. W dotychczasowej historiografii zagadnienie współpracy Żydów ze skarbem państwowym w XVII i XVIII w. było wzmiankowane jedynie marginalnie. W najnowszych badaniach uwage koncentrowano przede wszystkim na wybitnych jednostkach, czyli

${ }^{1}$ Przecław Mojecki, Żydowskie okrucieństwa, Kraków 1589; cyt. za: Ignacy Schiper, Dzieje gospodarcze Żydów Korony i Litwy w czasach przedrozbiorowych, [w:] Żydzi w Polsce Odrodzonej. Działalność społeczna, gospodarcza, oświatowa i kulturalna, t. 1, red. Ignacy Schiper, Arjeh Tartakower, Aleksander Hafftka, Warszawa [1933], s. 153. 
przedstawicielach żydowskich elit ekonomicznych, dla których dzierżawa dochodów państwowych była jedynie etapem w ich karierze ${ }^{2}$. Brak jednak badań, które przedstawiają współpracujących ze skarbem państwowym Żydów widzianych z perspektywy ich codziennej pracy.

W moim artykule przedstawię działalność żydowskich celników arendujących cła i myta od skarbu państwowego i królewskiego. Interesują mnie następujące zagadnienia: jakie były formy arendy ceł? czy było to zajęcie typowe dla Żydów litewskich? jak wyglądała codzienność pracy żydowskich celników? Dodatkowym założeniem jest ukazanie roli, jaką odgrywali Żydzi w administracji skarbowej, i przyjrzenie się funkcjonowaniu instytucji skarbowych dawnej Rzeczypospolitej na poziomie pracowników niższych szczebli.

Badaniami pod tym kątem zostało objęte Wielkie Księstwo Litewskie (dalej: WKL), a wybór tego obszaru nie był przypadkowy. Po pierwsze - bardziej liberalne prawo litewskie pozwalało Żydom na szerszy zakres współpracy ze skarbem państwowym niż w Koronie ${ }^{3}$. Po drugie - litewskie materiały skarbowe są dużo lepiej zachowane niż koronne, dzięki czemu mogą stanowić podstawę do analizy współpracy Żydów ze skarbem państwowym.

Ramy chronologiczne niniejszych rozważań zamykają się w stuleciu rozpoczynającym się w połowie XVII, a kończącym w II połowie XVIII w.

${ }^{2}$ Por. Maurycy Horn, Żydzi na Rusi Czerwonej w XVI i pierwszej połowie XVII w. Dziatalność gospodarcza na tle rozwoju demograficznego, Warszawa 1975, s. 220-241; Israel Sosis, Der jdiszer sejm in Lite un Wajsrusland in zajn gezecgeweriszer tetikajt (1623-1761) lojt zajne protokoln, „Cajtszritf” 2-3 (1928), kol. 1-72; por. także ogólne wzmianki w pracach Majera Bałabana: Majer Bałaban, Historia Żydów w Krakowie i na Kazimierzu 1304-1868, Kraków 1936; tenże, Żydzi lwowscy na przełomie XVI-go i XVII-go wieku, Lwów 1906; zob. też: Maria Cieśla, Łazarz Mojżeszowicz - przykład żydowskiej kariery w Wielkim Księstwie Litewskim w połowie XVII wieku, „Kwartalnik Historyczny” 112 (2005), nr 4, s. 4-29; taż, Mojżeszowicz, Gordon, Ickowicz: The Jewish Economic Elites in the Grand Duchy of Lithuania (Seventeenth and Eighteenth Century), „Acta Poloniae Historica” 107 (2013), s. 101-127; Jürgen Heyde, Transkulturelle Kommunikation und Verflechtung: Die jüdischen Wirtschaftseliten in Polen vom 14. bis zum 16. Jahrhundert, Wiesbaden 2014; Cornelia Aust, Merchants, Army Suppliers, Bankiers: Transnational Connections and the Rise of Warsaw's Jewish Mercantile Elite (1770-1820), [w:] Warsaw. The Jewish Metropolis: Essays in Honor of the 75th Birthday of Professor Antony Polonsky, red. Glenn Dynner, François Guesnet, Leiden-Boston 2015, s. 42-69.

${ }^{3} \mathrm{Na}$ temat różnic w pozycji prawnej Żydów w Koronie i w WKL por.: Maria Cieśla, Sharing a Commonwealth - Polish Jews or Lithuanian Jews, „Gal-Ed” 24 (2015), s. 15-44; Jurgita Šiaučiūnaitè-Verbickienė, Žydai Lietuvos Didžiosios Kunigaikštystès visuomenëje. Sambūvio aspektai, Vilnius 2009. Prawa i przywileje mające wpływ na żydowskich współpracowników skarbu zostaną szczegółowo omówione w dalszej części artykułu. 
Wybór pierwszej z cezur został podyktowany stanem zachowania materiałów źródłowych. Nie ma bowiem dokumentów skarbowych z I połowy XVII w., natomiast dobrze zachowane są materiały z połowy XVII w. Pod koniec lat czterdziestych XVIII w. Żydzi ograniczyli współpracę ze skarbem WKL, dlatego też połowa tego wieku stanowi cezurę końcową moich rozważań. W przeciwieństwie do wcześniejszych okresów zagadnienie współpracy Żydów ze skarbem państwowym w XVII i XVIII w. nie zostało dotychczas omówione w literaturze przedmiotu. Jednym z celów tego artykułu jest zatem pokazanie, że dzierżawą podatków państwowych - zajęciem typowym dla przedstawicieli żydowskich elit finansowych w XV i XVI stuleciu ${ }^{4}$ - trudnili się Żydzi również w wiekach XVII i XVIII.

Podstawę źródłową moich rozważań stanowią przede wszystkim dokumenty skarbowe przechowywane w dziale tzw. Komisji Skarbowej w Litewskim Państwowym Archiwum Historycznym w Wilnie, Akta Trybunału Skarbowego, akty Metryki Litewskiej, a także pojedyncze dokumenty pochodzące $\mathrm{z}$ archiwów magnackich (Archiwum Radziwiłłów) oraz z wybranych ksiąg grodzkich. Posiłkowałam się również dokumentami wydanymi przez Wileńską Komisję Archeograficzną. Dokładne przedstawienie działalności żydowskich celników nie jest możliwe ze względu na niekompletne źródła, przy czym szczególnie trudno jest opisać pracę żydowskich pracowników zatrudnianych przez oficjalnych arendarzy podatku. O ich działalności dowiadujemy się najczęściej z akt procesów odbywających się przed sądem asesorskim albo przed Trybunałem Skarbowym. Zachowało się bardzo mało źródeł mówiących o organizacji codziennej pracy w komorach celnych. Taka specyfika materiału źródłowego powoduje, że wiele pytań postawionych w tym artykule musi pozostać bez odpowiedzi.

Do przedstawienia pracy żydowskich celników mało pomocna jest dotychczasowa literatura przedmiotu. Funkcjonowanie systemu podatkowego i skarbowości dawnej Rzeczypospolitej zostało dość dobrze opisane. Jak dotąd zagadnienia te analizowane były przede wszystkim z perspektywy

${ }^{4} \mathrm{Na}$ temat współpracy Żydów ze skarbem w dawnej Rzeczypospolitej opublikowano m.in. następujące prace: Maurycy Horn, Żydzi i mieszczanie w stużbie celnej Zygmunta Starego i Zygmunta Augusta, „Biuletyn Żydowskiego Instytutu Historycznego” 141 (1987), s. 3-20; Heyde, Transkulturelle Kommunikation..., s. 162-211; Siergiej Aleksandrowicz Bierszadski, Awram Jezofowicz Riebiczkowicz, Kijew 1888; tenże, Litowskije jewriei. Istorija ich juridiczeskogo i obszczestwiennogo położenija w Litwie ot Witowta do Lublinskoj unii. 1388-1569 g., Sankt Petersburg 1883. 
życia politycznego kraju. Wyjątkiem są tutaj najnowsze badania Anny Filipczak-Kocur, które szczegółowo przedstawiają materiały źródłowe dotyczące arendy ceł w WKL 5 .

\section{Cła i ich dzierżawy}

Cła w WKL były podatkiem nadzwyczajnym, uchwalanym w razie potrzeby na sejmie. W I połowie XVII w. cła nie były wprowadzane co roku', jednak wraz z pogarszaniem się sytuacji finansowej kraju uchwalano je na każdym sejmie. Opłaty pobierano zgodnie z regularnie publikowanym instruktarzem celnym. Oprócz ceł uchwalanych na sejmach i należących do dochodu skarbu państwowego pobierano także tzw. cła stare albo myta - podatek od przewożonych towarów, z którego dochód należał do skarbu nadwornego i był przeznaczony na utrzymanie króla. W większości wypadków obydwa rodzaje podatków pobierano na tych samych komorach celnych ${ }^{7}$. Dlatego też w dalszych rozważaniach traktuję współpracowników skarbu nadwornego oraz skarbu państwowego jednakowo, nie rozróżniając celników i mytników, a także skarbu nadwornego i skarbu państwowego.

Pobór ceł oddawano w dzierżawę, stosując zasadę plus offerendum - to znaczy wyboru osoby, która była w stanie zapłacić najwięcej. Najczęściej prócz oficjalnej sumy wpłacanej do skarbu państwowego pobierano także tzw. rękawiczne, czyli opłatę dla podskarbiego. Szerokie stosowanie arend w systemie skarbowym WKL miało wiele zalet. Powodowało m.in. zmniejszenie zakresu obowiązków podskarbiego, co obniżało koszty oraz upraszczało funkcjonowanie administracji skarbowej.

${ }^{5}$ Roman Rybarski, Skarb i pieniadz za Jana Kazimierza, Michała Korybuta i Jana III, Warszawa 1939; Michał Nycz, Geneza reform skarbowych Sejmu Niemego: Studium z dziejów skarbowo-wojskowych 1697-1717, Poznań 1938; Anna Filipczak-Kocur, Skarb litewski za pierwszych dwu Wazów (1587-1648), Wrocław 1994; taż, Skarbowość Rzeczypospolitej 1587-1648. Projekty - ustawy - realizacja, Warszawa 2006; taż, Cła litewskie 1630-1634 ( z dziejów skarbu Wielkiego Księstwa Litewskiego za podskarbiostwa Stefana Paca), „Studia z Dziejów Państwa i Prawa Polskiego" 11 (2008), s. 87-100; Andrzej B. Zakrzewski, Wielkie Księstwo Litewskie (XVI-XVIII w.). Prawo - ustrój - społeczeństwo, Warszawa 2013, s. $149-166$.

${ }^{6}$ Cło uchwalano w latach 1633, 1635, 1643, 1647. Filipczak-Kocur, Skarb litewski..., s. 38; Zakrzewski, Wielkie Księstwo Litewskie..., s. 152.

7 Filipczak-Kocur, Skarb litewski..., s. 10-20.

${ }^{8}$ Rybarski, Skarb i pieniadz..., s. 41; Stanisław Kościałkowski, Ze studiów nad dziejami ekonomii królewskich na Litwie, Wilno 1914, s. 40; Nycz, Geneza reform..., s. 17. 
Praktykowano kilka form dzierżawy. Można było przekazać prawa do poboru wszystkich ceł jednej osobie. Podpisanie kontraktu było formą gratyfikacji udzielanej osobom zasłużonym dla dworu'. Wypadki oddania w dzierżawę wszystkich ceł były nawet w środowisku chrześcijańskim raczej rzadko praktykowane, tego typu kontrakt wymagał bowiem od arendarza bardzo dużych nakładów finansowych.

Najczęściej dochodziło do sytuacji, w której cła pozostawały w administracji skarbu. Wtedy to podskarbi podpisywał kontrakty na dzierżawę konkretnych komór celnych lub poboru na określonym obszarze. Niezależnie od tego, jakiego rodzaju kontrakt podpisywano na poziomie centralnym, poszczególne miejsca poboru podatku wydzierżawiano tzw. subkolektorom lub kontrahentom.

Cło było inkasowane na komorach i przykomorkach celnych. Konstytucje sejmowe nadawały podskarbiemu prawo do zakładania komór i przykomorków w dowolnych miejscach, przy czym z powodów oczywistych lokowano je zazwyczaj przy najważniejszych drogach handlowych ${ }^{10}$. Skarb litewski nie miał fachowej kadry urzędniczej, która mogłaby się zajmować egzekucją podatków. Do obowiązku dzierżawców należało więc zorganizowanie poboru.

Wydaje się, że Żydzi stanowili najodpowiedniejszą grupę społeczną do podjęcia się obowiązku administrowania cłami w WKL. Decydowały o tym przede wszystkim kwalifikacje zawodowe. W społeczności chrześcijańskiej panowało przekonanie, ,że Żydzi wszystkie swoje rozchody z przychodami miarkować i napisywać lepiej niż chrześcijanie umieją i nadto Żyda nie znajdzie, co by pisać i rachować nie umiał"11. Żydzi najczęściej umieli czytać i pisać, posiadali także podstawowe umiejętności w zakresie rachunków ${ }^{12}$. Dodatkowe kompetencje zdobywali, pracując na komorach celnych przez wiele lat i przekazując tę profesję z pokolenia na pokolenie. Dzięki prowadzonym na szeroką skalę operacjom finansowym niektórzy z nich dysponowali płynną gotówką, konieczną do zainwestowania w nowo nabytą dzierżawę, szczególnie na pierwszym jej etapie.

${ }^{9}$ Filipczak-Kocur, Cta litewskie..., s. 89.

${ }_{10}$ Rybarski, Skarb i pieniądz..., s. 39-42.

${ }^{11}$ Examen punktów od Hercyka Żyda na arendarzów mytnicy stuckiej podanych 9 maj 1682, Archiwum Główne Akt Dawnych [dalej: AGAD], Archiwum Radziwiłłów [dalej: AR] XXIII, t. 136, p. 8, s. 86-89.

${ }_{12}$ Daniel Stone, Knowledge of Foreign Languages among Eighteenth-Century Polish Jews, „Polin” 10 (1997), s. 200-220. 


\section{Celnicy żydowscy - aspekt prawny}

Angażowanie się Żydów w arendy dochodów państwowych ułatwiało korzystne prawo. Działalność gospodarcza Żydów w WKL ograniczona była wieloma zakazami. Szczególnie w miastach, gdzie mieszczaństwo chrześcijańskie było silne, wprowadzano ograniczenia żydowskiego handlu i rzemiosła ${ }^{13}$. Inne natomiast prawa obowiązywały w zakresie współpracy ze skarbem państwowym.

Na początku analizowanego okresu nie było żadnych przepisów prawnych precyzujących, kto ma prawo arendować dochody państwowe. Konstytucja sejmowa z 1565 r., zakazująca przejmowania arend dochodów państwowych przez Żydów, uchwalona jeszcze przed podpisaniem unii lubelskiej, obowiązywała jedynie w Koronie, a nie w WKL ${ }^{14}$. Analogicznego zakazu nie wprowadził także waad litewski. Żydzi, którzy chcieli podjąć współpracę ze skarbem państwowym, mieli jedynie obowiązek uzyskania odpowiedniej chazaki (zezwolenia). Poprzez ograniczenie wewnętrznej konkurencji gwarantowała ona żydowskim celnikom bezpieczeństwo dzierżawy ${ }^{15}$. Wydaje się, że najwyższe żydowskie władze autonomiczne do pewnego stopnia popierały swoich współwyznawców angażujących się w arendę dochodów państwowych. W 1623 r. starsi sejmu Waad Medinat Lite podkreślali, że: ,jeśli we wszystkich miejscowościach diaspory cła byłyby w rękach żydowskich, to Żydom by się dobrze wiodło”. Na kolejnych posiedzeniach waadu w latach dwudziestych i trzydziestych XVII w. podejmowano uchwały mające na celu zachęcenie Żydów do przejmowania dzierżaw dochodów państwowych, a także wzmocnienie ich starań. Zakazywano jedynie Żydom pracy w nowo powstających komorach celnych ${ }^{16}$.

Korzystne dla Żydów przywileje zaczęto zmieniać w połowie XVII stulecia. W 1661 r. po raz pierwszy w konstytucji uchwalającej nowo podwyższone cło oraz auctio subsidiorum została zawarta klauzula zakazująca Żydom dzierżawy tych podatków; analogiczny zapis powtórzono jeszcze

${ }^{13} \mathrm{Na}$ temat praw gospodarczych Żydów w WKL por. Cieśla, Sharing a Commonwealth..., s. 33-39.

${ }_{14} \dot{Z}$ eby cet, myt, etc. Żyd nie trzymat. Ze względów formalnoustrojowych ustawa ta nie miała mocy prawnej w WKL, ponieważ została uchwalona przed unią lubelską. Zdarzało się, że ustawy przedunijne obowiązywały w WKL, ale - jak pokazują dokumenty skarbowe - uzus w wypadku tej regulacji był inny. Volumina Legum [dalej: VL], wyd. Jozafat Ohryzko, t. 2, Petersburg 1859, s. 69.

15 Anna Michałowska-Mycielska, Sejm Żydów litewskich (1623-1764), Warszawa 2014, s. $128-131$.

16 Tamże, s. 127-130. 
w 1676 r. ${ }^{17}$ Dopiero w 1678 r. wprowadzono ustawę mówiącą o tym, aby „Żydzi i Tatarowie, i inni niewierni, tak w Koronie, jako i w WXL [...] ceł, myt ani żadnych prowentów Rzeczpospolitej per arendam nie trzymali ani Exaktorami onych nie byli”"18. Pod koniec wieku XVII w instrukcjach sejmikowych coraz częściej zaczyna się pojawiać postulat nieoddawania Żydom w administrację dochodów Rzeczypospolitej ${ }^{19}$. W 1703 r. niejaki Jakub Hendelowicz, Żyd słucki, o którym mówiło się w mieście, że podpisał kontrakt na pisarstwo komory rzeczyckiej, zeznawał:

wiadomości żadnej nie miał i nie ma, by najmniej wiedzieć o niej [komorze celnej - M.C.] nie chce nie tylko dlatego, że od wieku swego cła nie zawiadywał, ale też, że prawem pospolitym surowie to, aby Żydzi w komorach przykomorkach celnych za pisarzów nie zostawali, zakazano ${ }^{20}$.

W tym samym okresie coraz częściej w trakcie procesów z celnikami żydowskimi zaczynało się przywoływać konstytucje sejmowe, które zakazywały arendy Żydom ${ }^{21}$. W 1712 r. Antoni Rudomina Dusiacki dostał przywilej królewski, który dawał mu prawo do ścigania i oskarżania żydowskich celników pracujących w komorach celnych w powiecie brasławskim ${ }^{22}$. Wydaje się, że przepisy te zaczęto egzekwować bardziej restrykcyjnie dopiero w połowie XVIII w. Od początku lat trzydziestych tego stulecia

17 Jak zapisano: „które w administracje [...] Wielmożnemu Adamowi Maciejowi Sakowiczowi Woiewodzie Smoleńskiemu Administratorowi Skarbu naszego W.X. Lit. daiemy, aby z naylepszym pożytkiem y wygodą Rzplitej plus offerendi Reipub. chrześcijaninowi bene possesionato arendował” - VL, t. 4, s. 383. „Żydzi przy tym, aby do żadnych komór celnych według konstytucji 1662 aplikowani nie byli" - VL, t. 5, s. 209.

${ }_{18}$ VL, t. 5, s. 115.

${ }^{19} \mathrm{~W}$ instrukcji wiłkomierskiej na sejm 1699 r. zapisano: „Gdyby jednak Rzpta potrzebowała jakiegoś nadzwyczajnego podatku, jego administracja w żadnym razie nie może przypaść Żydowi, a obecnym poborcom" - zob. Ukmerges pilies teismo aktai knyga 16971702, Biblioteka Uniwersytetu Wileńskiego, Dział Rękopisów [dalej: VUB], sygn. F. 7, k. 84v. W instrukcji smoleńskiej z 1701 r. czytamy: „A jeśli by, który in posterum z ludzi cudzoziemskich albo Żydów do administracii jakichkolwiek intrat skarbowych odważył się, takowy ma być pro perdito et invidicabili capite" - Lietuvos Valstybes Istorijos Archyvas, Senieji Aktai [dalej: LVIA, SA] 4716, k. 1635. Dziękuję Przemysławowi Romaniukowi za zwrócenie uwagi na zapisy instrukcji poselskich.

${ }_{20}$ Zeznanie Jakuba Hendelowicza, 4 października 1703 r., Narodowe Historyczne Archiwum Białorusi w Mińsku, sygn. F. 1739, op. 1, nr 6, bez paginacji.

${ }^{21}$ Postanowienie komisarskie między Jlia Tyfanem kupcem moskiewskim a Aronem ojcem i Michałem Gordonem Żydami wileńskim, Akty izdawajemyje Wilenskoj archieograficzeskoj komissijej, t. 29: Wilna 1870-1899, nr 179; Dekret oczywisty w sprawie pana Wołowicza stolnika mińskiego z Żydami mińskimi - LVIA, SA 2425, nr 74.

${ }_{22}$ Consens Antoniemu Rudominie, aby przestrzegat praw sanctorum regni principaliter ratione Żydów na komorach i przykomorkach w powiecie brasławskim, 22 kwietnia 1712 r., Metryka Litewska [dalej: ML] 156, nr 6. 
w źródłach coraz rzadziej można napotkać żydowskich celników. Ostatni znany mi proces, jaki wytoczono Żydom pracującym na komorze celnej na Żmudzi, odbył się na forum Trybunału Skarbowego w 1748 r. ${ }^{23}$

\section{Liczebność celników żydowskich}

Ze względu na specyfikę źródeł, jakimi dysponuję, nie można dokładnie stwierdzić, jak liczna była grupa żydowskich celników. Nie zachowały się żadne źródła masowe pozwalające na pokazanie jakichkolwiek danych liczbowych dotyczących tej grupy. Problemem w badaniach jest także rozproszenie i niejednoznaczność źródeł. Jedynie w wyjątkowych wypadkach arenda całości dochodu była powierzana Żydom bezpośrednio ze skarbu. W takich sytuacjach oficjalnie podpisywane kontrakty zachowały się w materiałach skarbowych.

Najczęściej jednak Żydzi zawierali kontrakty z oficjalnymi arendarzami skarbu na podstawie prywatnych umów, które albo się do naszych czasów nie zachowały, albo przechowywane są w różnych tzw. archiwach podworskich. Nieliczne tego typu dokumenty w sposób zupełnie przypadkowy były aktykowane w księgach grodzkich. O pracy Żydów najczęściej można się dowiedzieć, gdy wybuchały konflikty i sprawy te trafiały do sądów. Zrozumiałe, że w źródłach sądowych zachowały się wzmianki jedynie o niektórych żydowskich celnikach. Analizując skalę zjawiska, należy podkreślić, że w większości źródeł najczęściej pojawiają się jedynie oficjalni arendarze, czyli przedstawiciele elit, podczas gdy przy poborze pracowały także osoby zatrudniane przez oficjalnych arendarzy. Wydaje się, że grupa pracowników niższego stopnia była najliczniejsza, nie zachowały się jednak żadne materiały źródłowe pozwalające na jej oszacowanie.

W ogólnym obrazie struktury zawodowej Żydów litewskich arenda ceł nie była ważnym zajęciem, w skali całej wspólnoty bowiem jedynie niewielka grupa osób trudniła się poborem podatków. Należy jednak zwrócić uwagę, że Żydzi wśród współpracowników skarbu musieli stanowić dość widoczną grupę, być może dużą liczebnie, o czym zdają się świadczyć częste wzmianki w takich źródłach, jak: instrukcje sejmikowe, protestacje czy utwory antyżydowskie. Widoczne jest to również w materiałach sądowych. Na przykład w procesie o niewpłacenie przez arendarzy poszczególnych

${ }^{23}$ Remisyja per generalem księżny z Zawiszów Radziwitlowej, wojewodziny nowogródzkiej z panem Józefem Tyszkiewiczem, starosta żmudzkim i niewiernymi Żydami, 28 września 1748 r., LVIA, SA 2438, nr 405. 
komór celnych powinności z cła starego w $1670 \mathrm{r}$. zostało oskarżonych 24 arendarzy komór celnych z całego obszaru WKL, wśród których tylko 6 osób nie było Żydami²4.

\section{Chronologia zjawiska}

Z zachowanych źródeł można by wnioskować, że podejmowanie przez Żydów współpracy ze skarbem państwowym było bardziej rozpowszechnione w XVII niż w XVIII w. Na pewno w XVII w. więcej Żydów przejmowało dzierżawy ceł, znamienne było także zawieranie dużych kontraktów bezpośrednio ze skarbem zarówno nadwornym, jak i państwowym. Natomiast w XVIII w. coraz mniej Żydów współpracowało ze skarbem, prawie nie zdarzało się, aby przejmowali oni generalne arendy ceł. Zjawisko to miało kilka przyczyn. Po pierwsze, pewne znaczenie miały opisywane powyżej zmiany w prawie oraz coraz bardziej restrykcyjne przestrzeganie przepisów zarówno przez urzędników skarbowych, jak i przez samych Żydów. Drugim ważnym aspektem wydaje się coraz silniej odczuwalna pauperyzacja ludności żydowskiej, widoczna zwłaszcza od II połowy XVII w. Zjawisko to powodowało, że coraz mniej osób dysponowało odpowiednimi kapitałami niezbędnymi do podjęcia współpracy ze skarbem państwowym ${ }^{25}$. Pewną rolę odgrywała także postępująca decentralizacja i wzrost znaczenia, także gospodarczego, dworów magnackich ${ }^{26}$. Wielu Żydów decydowało się na współpracę z dworami magnackimi, gdyż te dawały większe możliwości zarobkowania niż centralne instytucje państwowe ${ }^{27}$.

${ }^{24}$ Kontumacja Drzewieckiemu skarbnemu lubelskiemu na Żydów celnych cła starego WKsL, 19 maja 1670 r., ML 360, k. 797v-799v.

${ }_{25}$ Jakub Goldberg, Armut unter den Juden im Alten Polen, [w:] Juden und Armut in Mittel- und Osteuropa, red. Stefi Jersch-Wenzel, Köln-Weimar 2000, s. 71-91.

${ }^{26}$ Antoni Mączak, Rządzący i rządzeni. Władza i społeczeństwo w Europie wczesnonowożytnej, Warszawa 2002, s. 122-128.

${ }^{27}$ Gershon D. Hundert, Was There an East European Analogue to Court Jews?, [w:] The Jews in Poland, t. 1, red. Andrzej K. Paluch, Kraków 1992, s. 73-75; Adam Teller, Telling the Difference: Some Comparative Perspectives on the Jews' Legal Status in the Polish-Lithuanian Commonwealth and the Holy Roman Empire, „Polin” 22 (2009), s. 109-141. Na temat funkcjonowania Żydów w ramach dóbr magnackich w WKL por.: tenże, The Legal Status of the Jews on the Magnate Estates of Poland-Lithuania in the Eighteenth Century, „Gal-Ed” 15-16 (1997), s. 41-63; tenże, Money, Power, and Influence in the Eighteenth-Century Lithuania: The Jews on the Radziwilt Estates, Stanford 2016; Moshe Rosman, Żydzi pańscy. Stosunki magnacko-żydowskie w Rzeczypospolitej XVIII wieku, tłum. Wojciech Tyszka, Warszawa 2005. 


\section{Warunki współpracy i obowiązki arendarzy ceł}

W analizowanym okresie rzadko podpisywano oficjalne umowy przekazujące dzierżawę całości dochodów Żydowi bezpośrednio ze skarbu państwowego. W zgromadzonym materiale źródłowym udało się znaleźć tylko kilka tego typu przykładów. W latach 1631-1633 pobór trzech czwartych cła nowo podwyższonego ze spławem wodnym został wydzierżawiony Łazarzowi i Samuelowi Mojżeszowiczom ${ }^{28}$. W 1661 r. Łazarzowi Mojżeszowiczowi powierzono arendę zarówno uchwalonego w tym roku cła auctio subsidiorum, jak i cła nowo podwyższonego ${ }^{29}$.

Interesującym i wartym podkreślenia jest fakt, że bezpośrednie kontrakty z Żydami podpisywano także w II połowie XVII oraz w XVIII w., kiedy oficjalnie obowiązywała ustawa sejmowa zakazująca takiej praktyki. Na przykład, w 1689 r. król Jan III Sobieski przekazał w dzierżawę całość dochodów z ceł starych swojemu faktorowi i sekretarzowi Eliaszowi Izaakowiczowi oraz Ickowi Zelmanowiczowi ${ }^{30}$. W $1720 \mathrm{r}$. powierzono cło stare także faktorowi królewskiemu Pinkasowi Izaakowiczowi ${ }^{31}$. $\mathrm{Z}$ kolei arendarzem całości dochodów z ceł starych i ceł nowo podwyższonych był w 1704 r. również faktor królewski, Berens Leyman (Berendt Lehmann) $)^{32}$.

Również rzadko i w drodze wyjątku przekazywano bezpośrednio ze skarbu dożywotnią dzierżawę jednej komory celnej. W 1698 r. powierzono dożywotnie pisarstwo komory celnej dyneburskiej faktorowi skarbowemu Irszowi Izraelowiczowi, który wcześniej przez 16 lat arendował różne podatki od skarbu państwowego i dobrze wywiązywał się z obowiązków. Przywilej wydany z kancelarii królewskiej dawał mu prawo do

${ }^{28}$ Filipczak-Kocur, Cta litewskie..., s. 94. Na temat rodziny Mojżeszowiczów zob.: Cieśla, Łazarz Mojżeszowicz..., s. 5-29; taż, Mojżeszowicz, Gordon ..., s. 101-127.

${ }^{29}$ Liczba Jaśnie Wielmożnego M. P. wojewody smoleńskiego administratora skarbu WXL starosty oszmiańskiego na sejmie teraźniejszym dwudzielnym in anni 162020 Februar w Warszawie odprawującym się tak z retent dawnych, jako i z prowentów na sejmie przyszłym uchwalonych poniżej specyfikowanych uczyniona, LVIA, SA 3411, k. 217v, 218v.

30 Przepisanie wszystkich cet WXL na Eliasza Izaakowicza, 24 lipca 1689 r., Akty izdawajemyje Wilenskoj archieograficzeskoj komissijej, t. 29, nr 129.

${ }_{31}$ Konfirmacja kontraktu na cło nasze niewiernemu Pinkasowi Izaakowiczowi, 3 kwietnia 1720 r., ML 159, k. 476-476v.

${ }^{32}$ Kontumacja jaśnie wielmożnemu panu staroście żmudzkiemu hetmanowi Polnemu WXL na Żyda Berensa Leymana, 28 marca 1705 r., LVIA, SA 2419, k. 68. O działalności politycznej Lehmanna zob.: Urszula Kosińska, Sondaż czy prowokacja? Sprawa Lehmanna z 1721 r., czyli o rzekomych planach rozbiorowych Augusta II, Warszawa 2009. 
dożywotniego sprawowania funkcji pisarza celnego i czerpania wszystkich korzyści z wykonywania tej pracy ${ }^{33}$.

Na Żydów celników generalnych nakładano określone obowiązki. Z kontraktu podpisanego z Łazarzem Mojżeszowiczem można się dowiedzieć, że był on zobowiązany do poboru cła według instruktarza celnego. Nakazano mu prowadzenie rejestrów cła, które po wygaśnięciu dzierżawy miał oddać podskarbiemu. Nałożenie na Żydów obowiązku spisywania i przekazywania rejestrów celnych wydaje się warte podkreślenia. Wiadomo bowiem, że chrześcijańscy kontrahenci skarbu nie zawsze musieli oddawać szczegółowe rozliczenia ze swojej działalności do władz skarbowych ${ }^{34}$. Trudno jednoznacznie rozstrzygnąć, z czego wynikała ta różnica. Może to wskazywać na nieco niższą pozycję żydowskich kontrahentów, którym - jak się wydaje - nie do końca ufano i dlatego nakazywano przedstawiać szczegółowe rozliczenia. Mniej dokładnie opisano obowiązki Eliasza Izaakowicza i Icka Zelmanowicza, zostali oni bowiem zobowiązani jedynie do organizacji poboru. Ponadto nadano im prawo do zakładania komór celnych i zatrudniania ich obsługi ${ }^{35}$. Podobne obowiązki ciążyły na Pinkasie Izaakowiczu, który w ciągu trzech lat obowiązywania umowy miał prawo do egzekucji tego podatku oraz do zatrudniania pisarzy celnych - chrześcijan i Żydów ${ }^{36}$.

Arendarz zobowiązany był wpłacać do skarbu ustalone z góry kwoty, nie zawsze zależne od faktycznego poboru. Wpłaty dokonywano w ratach - najczęściej dwa razy w roku. Sumy, którymi obracali celnicy generalni, były znaczne. Na przykład, na poczet cła nowo podwyższonego z 1630 r. Mojżeszowicze mieli wpłacić do skarbu państwowego 54 tys. zł. W 1631 r. za arendę tego samego podatku zobowiązali się przekazać kwotę 50 tys. zł. Natomiast za cło szlacheckie z lat 1631-1632 wpłacili oni do skarbu 57,5 tys. zł. W połowie lat trzydziestych XVII w. dochody z ceł znacznie wzrosły i Mojżeszowicze wpłacili do skarbu w 1634 r. kwotę 100 tys. zł37.

Arendarzom generalnym nie zawsze udawało się wywiązać z wszystkich powinności. W sytuacjach szczególnych, takich jak wojny czy zarazy, część opłat była im umarzana. Na przykład, w 1631 r. braciom Mojżeszowiczom ze względu na morowe powietrze umorzono 24 tys. zł. Zdarzało się także,

${ }_{33}$ Przywilej na pisarstwo komory dyneburskiej Irszowi Izraelowiczowi faktorowi naszemu, 20 lutego 1698 r., ML 149, f. 112.

${ }^{34}$ Filipczak-Kocur, Cta litewskie..., s. 90.

35 Przepisanie wszystkich cet WXL na Eliasza Izaakowicza, 24 lipca 1689 r., Akty izdawajemyje Wilenskoj archieograficzeskoj komissijej, t. 29, nr 29.

${ }^{36}$ Konfirmacja kontraktu na cło nasze niewiernemu Pinkasowi Izaakowiczowi...

${ }^{37}$ Filipczak-Kocur, Cta litewskie..., s. 97. 
iż rozliczenia ze skarbem prowadzono wiele lat po wygaśnięciu kontraktu. Przykładowo: w 1662 r. sukcesorzy Mojżeszowicza zalegali jeszcze z zapłatą 86952 zł do skarbu, z której to sumy umorzono im aż 76952 zł. Na tym samym sejmie wpłacono 2000 zł zaległych za arendę cła nowo podwyższonego. Wszystkie te rozliczenia dotyczyły arend z lat pięćdziesiątych i sześćdziesiątych XVII w. ${ }^{38}$

Na celników żydowskich określone obowiązki nakładały także uchwały waadu litewskiego. W źródłach żydowskich celnicy generalni traktowani byli jako szczególni przedstawiciele wspólnoty, którzy swoją wysoką w ramach społeczności chrześcijańskiej pozycję powinni wykorzystywać, aby ochraniać współbraci. Anna Michałowska-Mycielska dowodzi, że celników żydowskich zobowiązywano do pobierania mniejszych opłat od kupców żydowskich. Jednocześnie jednak przypominano im, że mają żydowskich przemytników karać surowiej niż chrześcijańskich, nakładając na nich dodatkowe kary pieniężne, których część miała być przeznaczona na cele dobroczynne ${ }^{39}$.

Powierzanie całości dochodów z ceł jednej osobie było raczej nietypowe. Wydaje się, że jedynie niewiele osób mogło zapłacić dużą sumę za dzierżawę tych podatków i miało tak dobrą pozycję u boku króla lub podskarbiego, aby móc wystarać się o bardzo dochodowe kontrakty. Druga forma zarobkowania w tym fachu - arenda pośrednia - była dużo bardziej rozpowszechniona. Najczęściej kontrakty zawierane były między osobami, które już wcześniej ze sobą współpracowały. Jeżeli szlachecki lub magnacki patron dostawał arendę dochodów ze skarbu państwowego lub królewskiego, to jej obsługę przekazywał swojemu żydowskiemu faktorowi, zlecając mu nadzorowanie całego lub części poboru. W zgromadzonym materiale źródłowym zachowało się wiele przykładów tego typu współpracy. Oto kilka z nich. W 1683 r. Andrzej Jan Niemcewicz, starosta hniewczycki i dworzanin pokojowy Jego Królewskiej Mości, dostał od skarbu królewskiego w arendę cło stare. Cały swój pobór wydzierżawił Izraelowi Lejzorowiczowi, „arendarzowi [swemu] hniewczyckiemu"40. Dziesięć lat później, w 1693 r., Bogusław Uniechowski współpracował z kilkoma żydowskimi arendarzami ceł ${ }^{41}$. Zdarzały się jednak także wypadki, w których komory celne arendowane były zupełnie obcym osobom, takim, które same zaoferowały swoją współpracę.

${ }^{38}$ LVIA, SA 3411, k. 217v, 218v.

${ }^{39}$ Michałowska-Mycielska, Sejm Żydów litewskich..., s. 130.

${ }^{40}$ Protestacja Jerzego Sowickiego, superintendenta cet podlaskich, 26 lutego 1698 r., Akty izdawajemyje Wilenskoj archieograficzeskoj komissijej, t. 29, nr 135.

${ }^{41}$ List zaręczny w sprawie sławetnych Paluszczyców z Żydami administratorami ceł W.X.L., 23 lipca 1693 r., ML 146, s. 711-712. 
W 1694 r. Jerzy Sowicki, superintendent komory pińskiej, skarżył się na Żydów - Marka Jakubowicza i Gierszona Beniaszewicza - którzy bardzo go prosili o dopuszczenie do spółki i wydzierżawienie tej komory. Po zawarciu kontraktu nie wywiązali się jednak z powinności ${ }^{42}$.

Obowiązki Żydów, którzy podpisywali arendę z oficjalnymi arendarzami, były zazwyczaj dokładnie takie same jak arendarzy generalnych, ale ograniczone tylko do jednej komory celnej. W kontraktach nakazywano Żydom zorganizowanie technicznej strony poboru. Natomiast w zamian za przekazanie arendy Żydzi wnosili na rzecz oficjalnego arendarza skarbu określoną opłatę. Podpisując umowę z oficjalnym dzierżawcą, Żyd najczęściej oddawał mu weksle na określone kwoty. W trakcie trwania kontraktu był zobowiązany w z góry określonych terminach, kilka razy w roku, do wykupywania swoich powinności. Wysokość tych opłat uzależniano od kilku czynników, przede wszystkim zaś od tego, jak dochodowa była komora celna ${ }^{43}$, i od długości trwania kontraktu. Różnice w kwotach, które wpłacali Żydzi za udzielenie im konkretnych arend, były znaczne. Na przykład Izrael Lejzorowicz za arendę ceł starych miał zapłacić Niemcewiczowi $400 \mathrm{z}^{44}$. Mimo że kontrakt nie precyzował dokładnie, jakie komory zostają arendowane, niewielka opłata wnoszona przez podarendarza może świadczyć o tym, że wydzierżawiana była tylko jedna z nich, mało dochodowa. Mojżesz Fajtelewicz, dzierżawiący od wojewody witebskiego Władysława Wołowicza dwie komory celne (w Mohylewie i Dziśnie) wraz ze wszystkimi przykomorkami cła auctio subsidiorum, w latach 1665-1667 zobowiązał się do zapłacenia 21178 zł za odstąpienie tej arendy. Wysoka opłata świadczy o tym, że spodziewano się z niej znacznego dochodu ${ }^{45}$. Podarendarze żydowscy nie kontaktowali się ze skarbem państwa, a dokonanie rozliczeń było obowiązkiem oficjalnego kontrahenta.

\section{Dochodowość arend}

Arenda dochodów państwowych była intratnym zajęciem, choć niestety trudno ocenić, ile zarabiali poszczególni arendarze. Wiadomo jedynie, jak wiele zarobił skarb państwa na danym podatku, nie wiemy natomiast, ile

${ }^{42}$ Protestacja Jerzego Sowickiego...

${ }_{43}$ Za najbardziej dochodowe uchodziły komory handlu północnego, mniejszy dochód przynosiły komory na drogach handlowych łączących wschód z zachodem. Filipczak-Kocur, Cta litewskie..., s. 98.

${ }^{44}$ Protestacja Jerzego Sowickiego...

${ }^{45}$ Między panem Wołowiczem, wojewoda witebskim hetmanem polnym WXL a niewiernym Mowsza Fajtelewiczem, Żydem wileńskim, 9 grudnia 1667 r., LVIA, SA 2411, nr 26. 
pieniędzy udawało się faktycznie zebrać. W opinii publicznej panowało przekonanie, że arendarze zarabiają znacznie więcej, niż wpłacają do skarbu. Pewne szczątkowe dane pokazują jedynie skalę dochodów. Na przykład, w 1592 r. Lew Sapieha miał zebrać na poczet myta starego ponad 132 tys. $\mathrm{z}^{46}$. W latach $1676-1678 \mathrm{z}$ ceł nowo podwyższonych przewidywany zysk miał wynosić 166 tys. zł ${ }^{47}$. Na tak duży zarobek mogli liczyć jedynie główni arendarze dochodów, dzierżawiący je w całości, dochody z „podarend" natomiast były znacznie mniejsze. Na dysproporcje w tym zakresie wskazują opisywane powyżej różnice w wysokości czynszów dzierżawnych pobieranych za poszczególne arendy. Dochód z ceł był w każdym roku inny, a duży wpływ nań miała sytuacja ekonomiczna kraju. W czasie wojen, szczególnie w połowie XVII w., kiedy życie gospodarcze w WKL prawie zupełnie zamarło, wpływy te musiały być dużo mniejsze niż w okresie pokoju i prosperity. Dochodowość ceł obniżały także zwolnienia z opłat wydawane przez króla różnym grupom społecznym.

Żydowscy celnicy czerpali również dodatkowe dochody pochodzące z udaremnianych przez nich prób przemytu towarów. Gdy odkryli przemyt, mieli prawo - zależnie od rodzaju umowy - do połowy lub jednej trzeciej wartości przemycanych towarów, resztę musieli oddać do skarbu ${ }^{48}$.

Wiadomo, że przedstawiciele najwyższych elit finansowych, współpracujący bezpośrednio ze skarbem państwowym i dzierżawiący dochody na dużym obszarze, gromadzili pokaźne majątki, co już opisałam we wcześniejszych publikacjach ${ }^{49}$. O tym, ile zarabiali podarendarze, źródła milczą. Należy jednak pamiętać, że Żydzi współpracujący ze skarbem państwowym stanowili grupę różnorodną pod względem zamożności - oprócz bogaczy znajdziemy w niej także osoby mniej zamożne.

\section{Pracownicy komór celnych}

W XVIII w. zadania arendarza dochodów państwowych opisywano w następujący sposób:

${ }^{46}$ Filipczak-Kocur, Cła litewskie..., s. 89.

47 Taryfa czopowego anno 1676 na sejmie coronationis uchwalonego za podskarbstwa jw. Jmp. Benedykta Pawła na Czerei Sapiehy podskarbiego wielkiego i pisarza ziemskiego W. Ks. Lit. różnym osobom za sumę w niej wyrażona arendowanego z wyrażeniem skarbowych honorariów i z osobistych pożytków ichm. pp. arendarzów specyfikacyja, AGAD, AR II, sygn. 1578, s. 37.

${ }_{48}$ Akt kontraktu Aronowi Aronowiczowi Rubinowiczowi, 20 maja 1720 r., LVIA, SA 13681, s. 195.

${ }^{49}$ Zob. np. Cieśla, Mojżeszowicz, Gordon..., s. 107-127. 
Wszak, by musiał na każdej komorze osadzić i ustanowić dyspozytorów, dependentów i dalsze potrzebne do zaspokojenia tych powinności osoby, potem do słuchania onych kalkulacyi od przychodowych i rozchodowych intrat komisarzów, na resztę dla ułatwienia zawilszych i prawnych interesów plenipotentów, a tych wszystkich przez wydane instrumenta na piśmie z determinowaną dla nich kapitulacyją i z wyrażeniem tych obowiązków, jakie która osoba miała w zleceniu odbywać 50 .

W komorach celnych potrzebni byli także pisarze i osoby rewidujące towary przewożone przez kupców. Skarb litewski nie miał określonej grupy pracowników zatrudnianych w komorach celnych. Podskarbi, który wydzierżawiał dochody, zupełnie nie ingerował w organizację poboru, pozostawiając arendarzom w tej sprawie wolną rękę. Oznaczało to, że o zatrudnianiu ludzi i organizacji pracy decydował zawsze arendarz - bez względu na to, czy był nim Żyd, czy chrześcijanin ${ }^{51}$.

Niestety nie zachowało się zbyt wiele źródeł, dzięki którym można by opisać organizacje pracy w komorach celnych arendowanych przez Żydów. Najczęściej zatrudniali oni jako pracowników swoich współwyznawców. Pracę w komorach celnych wykonywały spółki rodzinne - obok ojca (zazwyczaj głównego arendarza) pracowali tam także synowie i inni krewni. Przykładowo: w 1654 r. cło tabaczne na komorze mohylewskiej arendował Zusman Izaakowicz wraz z synem Lejbą. Trzydzieści lat później wraz z Lejbą Zusmanowiczem arendowali myta jego bracia - Mowsza i Jankiel Zusmanowicze. Z kolei w 1705 r. komorę jurborską dzierżawił Aron Gordon wraz ze swoim synem Michałem Gordonowiczem ${ }^{52}$. Ważne i warte podkreślenia jest także to, że spółki rodzinne przez całe lata zajmowały się dzierżawą jednej i tej samej komory celnej lub kilku komór celnych usytuowanych w bliskiej od siebie odległości. Zajęcie to było najczęściej dziedziczone w jednej rodzinie z pokolenia na pokolenie. Na przykład: w 1670 r. Ilia Mowszewicz, Żyd suraski, został oskarżony przez burmistrza i cały magistrat witebski o to, że nie przestrzegał ustaleń

${ }^{50}$ Odpowiedź Żyda Weytembera Dworów Cesarskiego y Bawarskiego Faktora na podane przeciw iemu przełożenie sprawy od J.O. Xsięcia Jmci Sapiehy wojewody połockiego, Hetmana Polnego W.X.Lit., [b.m.w.], [1775?], karty niepaginowane.

${ }_{51}$ Michał Kazimierz Pac wydzierżawił myta stare wcześniej powierzone mu ze skarbu królewskiego. Przekazanie cet starych WXL Leybie Zusmanowiczowi, 27 sierpnia 1684 r., Akty izdawajemyje Wilenskoj archieograficzeskoj komissijej, t. 29, nr 100; Heyde, Transkulturelle Kommunikation..., s. 169.

${ }_{52}$ Sprawa między Ilia Tufanem, kupcem moskiewskim, a niewiernymi Aronem i Michaelem Gordonami, Żydami wileńskimi, 27 listopada 1705 r., Akty izdawajemyje Wilenskoj archieograficzeskoj komissijej, t. 29, nr 179. 
dotyczących pobierania myta od kupców witebskich, które zostały zawarte jeszcze z jego ojcem, poprzednim arendarzem tej samej komory ${ }^{53}$. Natomiast Michał Gordonowicz, który w 1705 r. dzierżawił komorę jurorską, w 1717 r. był już superintendentem komory dyneburskiej ${ }^{54}$.

Jednak nie zawsze opierano pracę w komorach celnych tylko na członkach jednej rodziny. Żydowscy celnicy byli także pracodawcami dla wielu swoich współbraci ${ }^{55}$. Niewiele wiadomo o tego typu kooperacji, jednakże kilka zapisów źródłowych pokazuje, że chętnie zatrudniano przedstawicieli prowincjonalnej elity żydowskiej. Za przykład może służyć Icek Boruchowicz, pisarz na pińskiej komorze celnej, zatrudniony przez Łazarza Mojżeszowicza w latach czterdziestych XVII w. ${ }^{56}$ Jednak wielu żydowskich pracowników komór celnych jest znanych z jednego tylko dokumentu. Wiadomo jedynie, jak się nazywali i że nie należeli do elit, nawet tych lokalnych. Za przykład mogą tu posłużyć Żydzi Hirsz Izraelowicz i Aszor Aronowicz. W 1688 r. zostali oni oskarżeni wraz ze swoim pracodawcą Lejbą Zusmanowiczem o nieprawidłowości przy poborze ceł. Poza tym, że pracowali w komorach celnych, nic o nich nie wiadomo ${ }^{57}$.

Znane są jednak także sytuacje, w których Żydzi albo wchodzili w spółki z chrześcijanami, albo też zatrudniali chrześcijan jako pisarzy celnych. W 1717 r. Michał Gordonowicz, żydowski superintendent komory celnej w Dyneburgu, został oskarżony wraz ze swoimi współpracownikami - Stanisławem Januszewiczem i niejakim Babeckim - o nieprawidłowe pobieranie cła $^{58}$. Niestety nie wiadomo, kim oni byli i jaką wykonywali w komorach celnych prace.

${ }_{53}$ Cont. stawetnemu burmistrzowi i rajcom witebskim na niewiernego Mowszewicza, Żyda suraskiego, 24 grudnia 1670 r., ML 357, k. 206v-207v.

${ }^{54}$ Remisyja wielmożnego stolnika połockiego z Żydem Gordonowiczem i innymi, 22 października 1717 r., LVIA, SA 2421, nr 114. O wykorzystaniu koneksji rodzinnych w prowadzeniu interesów por. także: Maria Cieśla, Jewish Economic Elite in the Great Duchy of Lithuania in the 17th and 18th Century, [w:] La famiglia nell'economia europea secc. XIIIXVIII. The Economic Role of the Family in the European Economy from the 13th to the 18th Centuries, red. Simonetta Cavaciocchi, Firenze 2009, s. 497-509.

${ }_{55}$ Ignacy Schiper, Dzieje handlu żydowskiego na ziemiach polskich, Warszawa 1937, s. 156 .

${ }^{56}$ Mordechai Nadav, The Jews of Pinsk, 1506 to 1880, red. Mark Mirsky, Moshe Rosman, Stanford 2007, s. 100-101; Dekret między stawetnym magistratem kowieńskim a Pacem Kanclerzem, Marszałkiem i niewiernymi Żydami superintendentami, 14 lipca 1688 r., ML 369, k. 751-754v; Dekret w sprawie p. Kosakowskiej z Żydami pisarzami i strażnikami cta starego, 24 września 1717 r., LVIA, SA 2421, nr 16.

${ }^{57}$ Dekret między stawetnym magistratem kowieńskim...

${ }_{58}$ Remisyja wielmożnego stolnika połockiego... 
W niektórych wypadkach spółki żydowsko-chrześcijańskie były konieczne ze względu na niedostateczną znajomość przez Żydów języka polskiego i obowiązek prowadzenia wszystkich rejestrów celnych w tym właśnie języku. Zatrudnianie chrześcijan do pomocy przy obsłudze komór celnych mogło także zapobiegać oskarżeniom o znieważanie religii chrześcijańskiej poprzez nieodpowiednie traktowanie krzyża, który był niezbędny do przyjmowania przysięgi od kupców. W tym samym okresie w Koronie takie oskarżenia doprowadziły do osądzenia i bankructwa faktora królewskiego i celnika Jakuba Becala ${ }^{59}$.

Oprócz zatrudnienia obsługi technicznej komór superintendenci byli także zobowiązani do utrzymania budynków, mostów i innych obiektów należących do komór celnych. Niekiedy Żydzi sami budowali domy, w których zbierano podatki; na przykład w Jurborku został na mocy przywileju dla Żydów zwolniony z płacenia powinności miejskich „dom jeden skarbu JKM celny i mytnictwa, który własnym kosztem sprawców i pisarzów celnych jest zbudowany" ${ }^{\prime 0}$. Celnicy ponosili czasem również inne dodatkowe koszty. W rozliczeniach Michała Gordonowicza $\mathrm{z}$ arendy komory wileńskiej w latach 1708-1709 figurują takie pozycje, jak: „ekspens na koszt objęcia cła JKM od p. Przeździeckiego" oraz wydatki na dworzan i trębaczy zatrudnianych w czasie przejmowania arendy, a także koszty związane z produkcją pieczęci skarbowej ${ }^{61}$.

Jak wyglądała codzienna praca w komorze celnej, możemy się jedynie domyślać. Zachowany materiał źródłowy przekazuje niestety bardzo skąpe informacje na ten temat. A zagadnienie to wydaje się szczególnie interesujące. Pytanie o to, w jaki sposób udawało się żydowskim celnikom połączyć rygorystyczne nakazy religijne z obowiązkami narzucanymi przez kontrakt podpisany ze skarbem państwa czy magnackim patronem, z powodu braku źródeł musi pozostać bez odpowiedzi. Należy zdawać sobie jednak sprawę, że ten rodzaj pracy mógł powodować wiele problemów. Można się zastanawiać, jak żydowscy celnicy radzili sobie z obowiązkiem pracy w czasie świąt żydowskich i jak rozwiązywali problem kontaktu z niekoszernymi towarami przewożonymi przez kupców. Na pewno w tych miejscach, gdzie

${ }^{59}$ Adam Kaźmierczyk, Sprawa Jakuba Becala, żydowskiego faktora Jana III Sobieskiego w końcu XVII wieku, „Studia Historyczne” 35 (1992), nr 2, s. 155-171.

${ }^{60}$ Przywilej Cecylii Renaty dla Żydów jurborskich, 12 listopada 1644 r., Lietuvos magdeburginiu miestu privilegijos ir aktai. T. 1: Joniškis, Jurbarkas, oprac. Antanas Tyla, Vilnius 1991, nr 99.

${ }^{61}$ Sprawy celne, Biblioteka Czartoryskich w Krakowie, Dział Rękopisów, sygn. 2583, karty niepaginowane. 
prócz Żydów pracowali także chrześcijanie, ci ostatni mogli przejmować wiele obowiązków. Wydaje się jednak, że nie we wszystkich komorach celnych zatrudniano chrześcijan - w niektórych pracowali tylko Żydzi. Zachowany materiał źródłowy pokazuje jedynie, że w komorach celnych na co dzień używano języków żydowskich. Świadczą o tym adnotacje i obliczenia w alfabecie hebrajskim na marginesach rejestrów celnych pochodzących z pierwszych lat XVIII w. ${ }^{62}$

\section{Konflikty związane z pracą celników żydowskich}

Praca żydowskich celników wywoływała wiele kontrowersji. Był to temat często poruszany w publicystyce, na forach sejmikowych itd. Zazwyczaj oskarżano Żydów o to, że pracując w komorach celnych, bezprawnie uzurpują sobie władzę nad chrześcijanami. Argument ten jest jednak widoczny tylko w publicystyce. W znanych mi procesach sądowych, w których na ławie oskarżonych zasiadali żydowscy celnicy, oskarżenie to jednak nigdy nie pada. Przyczyny procesów z żydowskimi celnikami są najczęściej zupełnie inne.

W procesach tych Żydzi występują zarówno jako oskarżyciele, jak i oskarżający. Przed sądem asesorskim oraz Trybunałem Skarbowym toczyło się wiele spraw, w których żydowscy celnicy oskarżali o przemyt lub o bezpodstawne otrzymywanie z kancelarii królewskiej zwolnień celnych. Wyroki zazwyczaj kończyły się skazaniem winnych i nakazem oddania do skarbu zaległości podatkowych. Należy podkreślić, że w procesach tych celnicy występowali w imieniu władz skarbowych i domagając się spłaty zaległości podatkowych, działali na korzyść skarbu. W większości tego typu procesów pozycja żydowskich poborców podatkowych była dodatkowo wzmocniona, gdyż najczęściej występowali oni u boku swoich mocodawców, czyli - zależnie od tego, z kim podpisywali kontrakt - albo bezpośrednio z przedstawicielami skarbu, albo z oficjalnymi (chrześcijańskimi) dzierżawcami. Co więcej, to właśnie chrześcijanie wytaczali proces w imieniu żydowskiego poborcy ${ }^{63}$. Przykładowo, w latach pięćdziesiątych XVII w.

62 Tamże.

${ }^{63}$ Między p. Szaszewiczem skarbnym WksL wojskim kowieńskim a niewiernym Żydem Szymonem Józefowiczem succolectorem podatku czopowego, 26 października 1667 r., LVIA, SA 2411, nr 172; Między p. Soltanem Podkomorzym Starodubowskim administratorem czopowego powiatu stonimskiego a Żydem Zelmanem Oszarowiczem, 12 grudnia 1667 r., LVIA, SA 2411, nr 287. 
Samuel Salomonowicz i Wulf Izaakowicz, celnicy mohylewscy, wygrali sprawę z kupcami, którzy zostali oskarżeni o niezapłacenie myta i o namawianie innych kupców do przemytu. Oskarżeni Łukian Radzikiewicz i jego syn Marek spowodowali straty dla skarbu w wysokości 1,5 tys. zł, którą to sumę celnicy mieli prawo wyegzekwować na wszystkich dobrach ruchomych i nieruchomych tych mieszczan ${ }^{64}$. Często celnicy oskarżali także całe miasta o niesłuszne korzystanie ze zwolnień celnych, które bardzo zmniejszały możliwość zarobku arendarzy. Niekiedy postępowania tego typu odnosiły skutek, jak np. w przypadku Łazarza Mojżeszowicza, któremu udało się w kilku procesach doprowadzić do skasowania przywilejów zwalniających mieszczan witebskich z opłacania ceł ${ }^{65}$.

Podobnie silną pozycję w sądzie mieli także Żydzi, którzy oskarżali chrześcijan o napady, rozboje czy kradzieże w miejscach oficjalnego poboru podatku. Także w tych procesach podkreślano, że wskutek kradzieży czy pobicia żydowskiego poborcy ucierpiał przede wszystkim skarb państwowy. Doskonałym przykładem są tu sformułowania zawarte w akcie oskarżenia niejakiego Grotowskiego, który w 1677 r. „,bezprawnie, samowolnie na dom żydowski w Rudnikach w nocy napadłszy [...] sług skarbowych, biegunów, którzy gościńców pilnują, pobił [...]. Do tego skarbowych pieniędzy niemało zabrał"66.

Na ławę oskarżonych trafiali też żydowscy celnicy, których pomawiano o nieprawidłowości przy pobieraniu ceł. Kupcy zarzucali im zwykle ściąganie zbyt wysokich opłat. Michał Gordonowicz, superintendent komory jurborskiej, został w 1717 r. oskarżony o podwójne pobranie cła od kupca moskiewskiego, który - jego zdaniem, niesłusznie - musiał zapłacić 7 tys. zł podatku ${ }^{67}$. Celników oskarżano również o brutalność przy rewidowaniu towarów. Na przykład, w 1696 r. Lejzer Morduchowicz, Żyd zbierający myto na komorze w Słucku, został oskarżony przez ojca Joanicjusza Przesmyckiego, wikarego cerkwi Przemienienia Pańskiego w Słucku, o gwałtowną rewizję wozu, którym jechał do chorego. Żyd, rewidując wóz wikarego, miał wyrzucić na ziemię skrzynkę z Przenajświętszym Sakramen-

${ }^{64}$ Między Samuelem Salomonowiczem i Wulfem Izaakowiczem Żydami mohilewskimi a Łukianem Radzikiewiczem i synem jego Markiem, 21 stycznia 1653 r., ML 343, k. 510-511.

${ }^{65}$ Kontumacyja Łazarzowi Mojżeszowiczowi na mieszczan witebskich, 21 lipca 1654 r., ML 331, nr 79.

${ }^{66}$ Kontumacyja JM p. Grotowskiemu na JM p. Czaplińskiego, 7 lipca 1677 r., LVIA, SA 2416, nr 53; Między p. Zygmuntem Drzewieckim a JM p. Lengwordem, 22 listopada 1667 r., LVIA, SA 2411, nr 230.

67 Sprawa między Ilia Tufanem, kupcem moskiewskim, a niewiernymi... 
tem oraz krzyż i księgi święte ${ }^{68}$. Żydowskim celnikom zarzucano świadome przetrzymywanie przewożonych towarów, co oczywiście powodowało straty finansowe ich właścicielom. Na przykład, w 1721 r. Zelik Jozelewicz, pisarz komory celnej, został oskarżony przez niejakiego Więckowicza o zatrzymanie przez tydzień wozów z towarami przewożonymi na sprzedaż ${ }^{69}$. Celnicy rekwirujący przemycane towary byli także narażeni na zarzuty kradzieży. W 1748 r. księżna Barbara z Zawiszów Radziwiłłowa skarżyła się na Abla Abrahamowicza, Jankiela Lejbusiewicza i Hirsza, którzy sługom księżnej na komorze celnej „wozy, konie, pieniądze i wszystkie rzeczy onych gwałtownie pozabierali"70. Kupcy z miast, którym udało się uzyskać zwolnienia z ceł, oskarżali Żydów o to, że nie respektowali tych przywilejów i ściągali od nich opłaty. Władze Kowna w imieniu kupców oskarżyły w 1688 r. Lejbę Zusmanowicza oraz jego pracowników o pobieranie myta od „miodów przaśnych, od ryb świeżych, od chmielu i lnu, od szkła”, które do tej pory były zwolnione z jakichkolwiek opłat. Poza tym oskarżyciele zarzucali celnikom otrzymanie „ad male narrata” przywilejów z kancelarii królewskiej, kasujących wcześniejsze prawa kupców kowieńskich, które zwalniały ich ze wszystkich opłat celnych ${ }^{71}$. Większość procesów tego typu kończyła się dla żydowskich celników niepomyślnie. Najczęściej musieli oni zwracać wpłaty celne, pokrywać koszty procesowe i rekompensować inne straty poniesione przez poszkodowanych kupców.

Zdarzały się również procesy, w których żydowscy poborcy byli oskarżani o nierozliczenie się ze skarbem lub zdefraudowanie pieniędzy zebranych na poczet podatku. Żydom zarzucano również uzurpację nienależnej im władzy. Doskonałym przykładem tego typu oskarżeń jest proces z nieznanym z imienia Żydem, poborcą myta tabacznego, który „kupców miejscami nienaznaczonymi sam przeprowadzał, a potem niesłusznie i niezwyczajnie swoje nieskarbowe kwity daje i z włościanami ugody czyni”72.

${ }^{68}$ Dekret wielebnego ojca Joanicjusza Przesmyckiego, wikarego cerkwi Przemienienia Pańskiego stuckiej z Leyzerem Morduchowiczem Żydem, 31 maja 1696 r., LVIA, dział 1280, s. 2070, $\mathrm{nr} 43$.

${ }^{69}$ Kontumacyja JWP Więckowiczowi podsadkowi trockiemu z JP Szpryngerem i Żydem Zelikiem, 17 października 1721 r., LVIA, SA 2424, nr 74.

${ }^{70}$ Remisyja per generalem księżny z Zawiszów Radziwiłtowej...

${ }^{71}$ Dekret między stawetnym magistratem kowieńskim a Pacem, kanclerzem marszałkiem i pisarzem i niewiernymi Żydami superintendentami, ML 369, k. 751-754.

72 Kontumacyja p. skarbnemu WksL na p. Cytmanowskiego, pisarza przykomorka połongowskiego i innych, 10 sierpnia 1677 r., LVIA, SA 2416, nr 72. Procesy, w których wysuwano takie same oskarżenia: Kontumacyja p. Janowi Bortkiewiczowi na Żyda Marka Wulfowicza, pisarza przykomorka rakiskiego, 8 sierpnia 1676 r., LVIA, SA 2416, nr 66; JM p. Bogdanowicz z JM p. Zelowiczem, 10 października 1720 r., LVIA, SA 2423, nr 77. 
O wyniku tych procesów, w których oskarżano Żydów celników o nieprawidłowości w ich pracy, decydowało to, że nie występowali tam jako urzędnicy skarbowi egzekwujący należności skarbu państwa, ale jako pracownicy administracji skarbowej niewywiązujący się z obowiązków czy nadużywający swoich stanowisk ${ }^{73}$.

\section{Zakończenie}

W podsumowaniu można stwierdzić, że w analizowanym okresie Żydzi litewscy, arendując cła, aktywnie współpracowali ze skarbem państwowym i królewskim. Widoczne jest, że odgrywali oni pewną rolę w lokalnej administracji skarbowej, przy czym warto podkreślić, że stanowili grupę fachowych pracowników o odpowiednich kwalifikacjach, zazwyczaj popartych wieloletnim doświadczeniem. Środowisko żydowskich współpracowników skarbu było silnie zróżnicowane wewnętrznie. Współpracę ze skarbem podejmowali zarówno przedstawiciele elit finansowych, jak i osoby mniej zamożne. Ci pierwsi byli najczęściej oficjalnymi arendarzami skarbowymi, zarządzali organizacją pracy w komorach celnych, ci drudzy zaś wykonywali w nich codzienne prace, rewidowali kupców, wydawali zaświadczenia i prowadzili rejestry celne.

Przedstawione tutaj przykłady pokazują, że wbrew wcześniejszym opiniom badaczy Żydzi chętnie współpracowali z centralnymi instytucjami państwowymi również w XVII i XVIII w. Skalę tego zjawiska będzie można oszacować na podstawie badań dotyczących współpracy Żydów ze skarbem państwa także na innych polach, czyli przy arendach innych podatków i powinności. Wydaje się, że badania tego typu pokażą wiele nieznanych dotychczas aspektów oddolnego funkcjonowania instytucji państwowych w dawnej Rzeczypospolitej.

Maria Cieśla

Instytut Historii PAN

Niemiecki Instytut Historyczny w Warszawie mciesla@ihpan.edu.pl, ciesla@dhi.waw.pl

${ }^{73}$ Przykłady tego typu procesów: Między p. Stefanem Korczem, podkomorzym lidzkim a niewiernymi Żydami lidzkimi, 16 października 1667 r., LVIA, SA 2411, nr 95; Między p. marszatkiem lidzkim i jego succolectorem czopowego a niewiernymi Żydami, 28 października 1667 r., LVIA, SA 2411, nr 98; Kontumacyja p. Wadziegolskiemu na Żyda Abrahamowicza succolectora czopowego powiatu kowieńskiego, 7 sierpnia 1677 r., LVIA, SA 2416, nr 59. 
